\title{
A scientific enquiry into the future
}

\author{
Johannes Gabriel
}

Received: 25 July 2013 / Accepted: 31 October 2013 / Published online: 26 November 2013

(C) The Author(s) 2013. This article is published with open access at Springerlink.com

\begin{abstract}
Thinking about the future in a scientific manner is often characterised by an illusion of knowledge, leading to precarious one-sidedness and false conclusions. The reasons for this are misinterpretations of core scientific concepts as well as vested interests in knowledge creation and scientific advice; these misinterpretations and interfering interests can prevail because there is no coherent set of rules on what a scientific enquiry into the future could look like. To provide a foundation for further discussion, this article takes the knowledge illusion seriously and drafts some epistemological concepts and methodological rules that could bridge this gap. Ways to think about the future in a scientific way correspond to scientific anticipation instead of knowledge creation, to a complex analytical worldview instead of determinism, to discourse and scepticism instead of critical rationalism, to illustrative thought experiments instead of explanatory prognoses, and to plausibility instead of probability. The concepts and rules for a scientific enquiry into the future developed in this article can help to clearly differentiate between multiple prognoses and scenarios, and to evaluate scenarios by scientific means.
\end{abstract}

Keywords Philosophy of science - Theory and methodology $\cdot$ Prognoses $\cdot$ Scenarios · Probability · Plausibility $\cdot$ Knowledge

\section{Introduction}

Foresight has become more relevant in modern times as the world is characterized by complex relations and uncertain developments [1, 2]. More and more scientists form various

J. Gabriel $(\bowtie)$

Institute for Applied Foresight Intelligence (IAFI), Berlin, Germany

e-mail: johannes.gabriel@iafi.de

URL: www.iafi.de disciplines think about future developments for the next 10 to 15 years using prognoses or creating scenarios. However, prognoses and probabilities have nothing to do with the future and scenarios are not per se a valid scientific instrument to think about the future. Moreover, thinking about the future in a scientific manner is often characterised by an illusion of knowledge and leads to precarious one-sidedness and false conclusions.

A first indication of an illusion of knowledge in science exposing the future is obvious: Scientific studies about the future are characterized by a huge variety in outcomes. An analysis of 90 scientific examinations of China's future which included books, articles, anthologies, working papers and presentations, authored by economists, scientists form the field of future studies or futures research ${ }^{1}$, political or regional or other social scientists - revealed that statements about the future of China (capturing the political and economic system) vary widely [3]. They spoke of China as a stable democracy with a market economy; as a monolith autocratic state regulating a capitalist system with Chinese characteristics; as a fragile autocratic one-party system facing serious economic and social deficiencies; as a fragile democratic system threatened by domestic power hubs and a distorted economy; as a network-based polity in combination with crony capitalism; as a failed state of warlords; and so on [3].

Most studies claim to know what China's future will look like. As judging statements about the future to separate the true from the false ones is impossible, the loudest voice among different scientific studies about China's future can create an illusion of knowledge. Such illusions sometimes have ideological traits so that they can "manifest themselves in, or underlie, the thought, speech, aims, interests, ideals, ethical

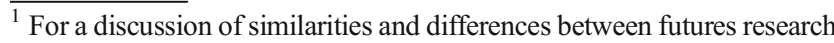
and future studies see The Millennium Project [48] and Pentti Malaskas' arguments [73].
} 
standards, actions - in short, the behaviour - of an individual human being." $[4,5]$. Hence, the illusion of knowledge in thinking about future is a serious problem, especially because it affects the way we plan and act strategically to shape the future, for instance in foreign policy.

Thinking about future using an illusion cannot be scientific, so the guiding question of this article is: How can we think about the future in a scientific way? This question refers to social scientists in general because they all think and write about the future and because they all - economists, futurists, political or other social scientists - claim to do it in a scientific way. First I illustrate four root causes for the illusion of knowledge in scientific thinking about the future before I draft some rules on how to think about the future or what a scientific enquiry into the future (SEF) could look like. ${ }^{2}$

\section{The illusion of knowledge}

\section{A forgotten fact about prognoses}

It should be clear that the future - a fundamental but virtual phenomenon of time, the thing we can just speak about in hypothetical terms because it simply has no factuality [6-9] cannot be known. The future is highly uncertain because we can neither fully grasp causes and effects nor all possibilities of future change in structures [3]. This becomes obvious if we think about future as history to-be: "If history is made by men, it cannot be foreknown" [10]. Although no one can know the future, social science still tries to do so because of a deeprooted misunderstanding about scientific knowledge. In order to elaborate my argument, I need to go into details here:

Science is the systematic, methodological, intersubjective creation of knowledge that is justified as true [11-14]. What is true knowledge?

One form of knowledge is based on the idea of causal relations. This causal concept of knowledge is based on strict and immutable interrelations (e.g. X causes Y). Natural sciences use causal justification but it is very problematic in the social sciences. The reliable concept of knowledge holds that correlations cannot always be strict and immutable, instead using probability as an indicator for the reliability of the method used to justify a conviction as knowledge (e.g. X probably causes Y under certain conditions) [15]. As there is no universal method to explain phenomena in social sciences, probability cannot be an objective indicator [16]. If there is more than one method to justify knowledge, there must be more than one kind of knowledge. The contextual conception of knowledge integrates this assumption by highlighting the role of different perspectives on knowledge - a scientific versus an everyday-

\footnotetext{
These rules derive from my dissertation, published in German in early 2013 [3]
}

life perspective, for instance. All concepts of knowledge can be found in various combinations, and it is plausible to assume that a final definition of knowledge is impossible [15, 17]. If there is more than one form of knowledge, it follows that there is more than one form of truth as well.

Three epistemic theories of truth are worth mentioning here. The pragmatic theory of truth excludes the assumption of a universal truth and states that statements can only be made true by verification and acceptance. In this theory knowledge has an instrumental character, with the disadvantage of also accepting lies as truth as long as they are useful [18]. The consensus theory by Jürgen Habermas defines truth as a conviction that obtains approval in a non-hierarchical discourse in which every participant has the chance to verify and criticise [19]. Whether such a discourse ever comes to an end is a question. The correspondence theory of truth involves the comparison of convictions with other scientific statements. Truth therefore cannot be attributed to a single statement. Instead it is inherent to coherent, bias-free theory systems. In this sense truth is always temporary and dependent on context [18]. As Hans Poser puts it, science cannot expect conclusions that are true in a general or universal sense but only general statements temporarily accepted as true [12].

This short discussion on knowledge and truth leads to an important insight: No matter which concept of knowledge or theory of truth is used in science, justification is needed to create acceptance, consensus, or coherence. The important question is not if a statement is eventually true or false because it could be true or false by chance. Much more important is the question of how science justifies the assessment of true and false convictions [15].

Because justifications must be able to answer the question why something is true, they are usually explanations. As explanations can never be universal (in the social sciences), they need to adequately meet four conditions to be accepted as a justification: The first condition indicates logical reasoning to explain something (the object of explanations is called explanandum). The second condition indicates the usage of a scientific law (an accepted theory) and a reference to why it can be applied for a certain explanation (scientific laws and basic conditions are called the explanans). The third condition indicates that the explanans has empirical significance and can be attributed to experience. The fourth condition indicates that the explanans must be true [12].

Adequately meeting these conditions is not easy. Scientific laws in social sciences cannot be universal, so they are also explanations and therefore temporary until they are - as Karl Popper pointed out - falsified [14, 20]. Because of the inherent possibility of falsification, all explanations in social science (explicitly or implied) use probability as a criterion for reliability.

All explanations using probability as a criterion are prognoses by definition. This means that all explanations in social science justified as true are in fact prognoses because theories, 
scientific laws, and explanations are not universal. Taking into account that the explanans needs to manifest empirical significance, it also becomes clear that prognoses by definition are scientific statements about the past, not about the future [3].

This fact went missing over time or is widely ignored despite the emergence of chaos theory and its implications for unpredictability [21]. Prognoses, contrary to the original concept, are assumed to create at least probable knowledge about the future when, in fact, they create knowledge about the past and probabilities have nothing to do with future.

The open questions about future studies and scenarios

More than others, futurists are aware of the fact that prognoses are problematic instruments to think about the (long-term) future. They were the first using scenarios systematically as an instrument to expose the future in a scientific way. Today, scenarios have become fashionable among social scientists from various disciplines [22, 23].

Scenarios are illustrations of possible pictures and histories of alternative futures. By definition, scenarios do not explicitly refer to probability or claim to reduce the future's uncertainty $[6,22-24]$. As the heart of future studies [24], scenarios are assumed to be scientifically better than prognoses when it comes to the challenge of addressing uncertain long-term developments. This is accepted in general but there are three important caveats:

First, future studies and futures research are de facto scientific disciplines but it is still discussed how scientific these discipline actually are [25]. This discussion is fueled by futurists who rightly highlight the role of creativity, fantasy and art [26-28], unfortunately giving scenario building an esoteric touch.

Second, 50 years of methodological development $[6,23$, 29, 30] have created - to use the words of the famous French futurist Michael Marien - a "methodological fog" [31], making it harder to define what scenarios are and how they can be constructed in a scientific way. "Today, the question of what scenarios are is unclear except with regard to one point - they have become extremely popular" [23].

Third, comprehensive foundations for a discipline of future studies or futures research are still missing [6, 32-36]. Of course, there is progress on the methodology and theory front of future studies to find ways to create better scenarios. ${ }^{3}$ However, rules for how to distinguish between good and bad scenarios in a scientific sense are still missing because rules to judge methodology or theory cannot be found in theory or methodology in itself.

Moreover, because prognoses have neither proved useless $[36,37]$ nor dismissed as an instrument to address the future

\footnotetext{
${ }^{3}$ See for example the discussions on Integral Futures and Causal Layered Analysis in the $2^{\text {nd }}$ issue of Futures in 2008.
}

[3], there is also no coherent set of rules to distinguish scenarios from prognoses and other forms of exposing the future. That said, it is no surprise that scenarios are often camouflaged prognoses, decorated with some creative ideas and presented as a compelling story [3].

The scientific community's hunt for knowledge

Science is a social system of collective knowledge, and scientific progress is a social phenomenon focusing on the proliferation of knowledge through research and transgenerational transmission at universities [38].

There are three major theories about scientific progress, and all three concern knowledge creation. Karl Poppers explains progress in theory development by falsification [14], Thomas Kuhn explains revolutions in research by changing paradigms [39], and Imre Lakatos describes progress in research as rational group behaviour [3, 12, 40].

Lakatos' theory of research progress offers an explanation of why knowledge creation is so important within the scientific community, showing too why an illusion of knowledge about the future is persistent. Competing research programs need to create more knowledge than others to survive. For the individual scientist there are strong incentives to conduct and publish research that adds to the research program's pile of knowledge. Doing so proves the relative quality of the research program. This not only serves the program's rational interest to survive but also the individual scientist's recognition and reputation. As a social process, science is intrinsically not free of individual and group interests [41-43].

In addition, the normative ideal of the universal law in social science still exists [12]. It was perhaps Karl Popper's critique of the universal truth claim and his orientation on rational falsification that promoted the search of universal laws and ideal explanations [6]. Even the long discourse on the progress of science, started in the beginning of the $20^{\text {th }}$ century, until today was not able to put the role of universal laws and ideal explanations into perspective $[3,12,39,40,44$, 45]. Social scientists tend to think about scientific progress in the sense of knowledge creation or at least further approximation through more and better scientific explanations. The scientific community's hunt for knowledge easily leads to an illusion of knowledge about the future.

The desire for security in scientific advice

Studying and solving practical problems is the social sciences' ultimate concern [43], and science claims to facilitate a "better life" [12] through scientific knowledge and social engineering [46]. Science therefore claims to support (societal) decisionmaking and planning, for instance in politics [47]. In addition to this supply side, a demand side for scientific advice thrives, creating a market for scientific advice on long-term future 
developments (in a broader sense, including all kind of organizations, not only from the political sphere) [48-50].

The future causes a special dilemma for planning and decision-making. On the one hand, it is inevitable for organisations (and of course also for individuals) to plan for the future [48]; on the other hand, approaching the future means to plan for the unknowable. Long-term planning and strategic decision-making is very difficult as they are laden with uncertainty, making decisions insecure with regard to their outcomes. Decision-makers can never know if they will make the right decision because they cannot fully grasp the current situation and they cannot foresee future developments. The more distant the future, the higher its uncertainty, and the higher the insecurity of present planning and decisionmaking situations in which scientific advice is highly welcome to generate good arguments as to why deciding for or against a certain strategic option [3].

Decision-makers have a strong interest in making their uncertain decisions more secure because success depends on decisions. Knowledge about the future is highly welcome because such knowledge is assumed to make insecure planning processes and decisions more secure for several reasons.

First, scientific knowledge can deliver relatively secure answers to complicated questions about an uncertain future because it is assumed that scientific knowledge is superior to everyday knowledge. An obvious example is the emerging role of expert opinion in politics. This trend is so powerful that Weingart and Lentsch rightly speak about a scientification of politics $[49,50]$. Second, knowledge can be exploited for strategic interests. In scientific advice, knowledge has to meet a certain set of criteria to be relevant: It has to be true in a scientific sense so that it is 'epistemically robust', and it has to be usable for political means so that it is 'politically robust' [50]. The latter means that in a context of scientific advice, scientific knowledge must be related to political interests. From this follows the third criterion, that knowledge can be easily used as a means to legitimise and justify a decision $[1,7$, 47, 50-53]. In sum, more scientifically justified knowledge about the future is often equalized with more security $[3,50]$.

Scenarios are useful tools for strategic decision-making and planning. The reason is that they can create a platform for communication, promote proactive and critical thinking, lay foundations for organizational strategic conversations, and help organisations to learn [23, 54-56]. In the end, however, scenarios cannot deliver what planners and decision-makers think they need the most: authority through secure decisions, based on rationally justified knowledge.

Would-be scenarios in the form of multiple prognoses are in turn assumed to be very useful to make insecure strategic situations more secure as they are meant to represent justifiable knowledge.

However, a high demand in scientific advice and a clear preference for prognoses or other forms of would-be knowledge about the future prevails because they are perceived as the pure form of knowledge about the future.

Warnings and reservations: the illusion of knowledge

There is a paradox in the scientific knowledge creation about the future. From a methodological perspective the knowledge paradox emerges from the fact that the more prognoses and scenarios produce scientific knowledge, the less they can expose the future in a scientific sense. Prognoses are probable explanations about the past. The more elaborated and sophisticated they are, the better they can approximate truth, the more they can predict the past, thereby becoming an useless instrument to expose the future in a scientific way. Scenarios are illustrations about alternative possible futures but the more scientific knowledge they create, the more they transform into multiple prognoses, the less they are useful as an instrument to scientifically expose the future.

The more a method aims to create scientific knowledge about the future by reducing its uncertainty, the more it must fail for a very simple and obvious reason: The future is uncertain and we cannot know the future. The knowledge paradox is reinforced by strong individual and group interests in knowledge creation among scientists (that includes wouldbe knowledge about the future to reduce its uncertainty) and among recipients (to reduce insecurity of strategic planning and decision-making).

With this knowledge paradox is dealt in two ways. One way is to apply ceteris paribus clause in scientific knowledge creation about the future. Another way is to apply a rebus sic stantibus clause in scientific advice that can often be found in concrete recommendations for strategic planning purposes. The ceteris paribus clause states constant cause and effect interrelationships over time and works as an analytical instrument to reduce complexity. This clause is perhaps useful for prognosis about the past but it is useless to create knowledge about the future because the price is much too high: Assuming constant interrelationships between causes and effects over time means neglecting structural and dynamic complexity, making future developments a linear extrapolation of the past, which in turn enforces a deterministic world view in which a free will cannot exist [3]. The rebus sic stantibus clause states that circumstances (of a certain situation) do not vary over time. Making a strategic plan or a decision is much easier under this assumption because it simply excludes dynamic complexity. The price for this assumption is high because strategic planning and decision making is then made under the assumption that there is a best decision to be made and that outcomes can be foreseen and controlled. Decisions made under this assumption inherently cause incidental consequences and can even create risks and threats to society, as Ulrich Beck pointed out [57].

Both ways to handle the knowledge paradox in a SEF may appear unproblematic at a first glance but, as my empirical 
evaluation of studies on China's future showed, it can easily lead to an illusion of knowledge that disqualifies a SEF [3]. The inconsiderate use of (multiple) prognoses about the future although sometimes explicitly stating the overall caveat of ceteris paribus or rebus sic stantibus - is a root-cause of a strong and, especially in the case of scenarios camouflaged as multiple prognoses, very convincing illusion of knowledge.

In that context, political robustness meets epistemic robustness in the illusion of knowledge, control, and security about the future, opening the door for a politicization of science and a would-be scientification of politics. As Michael Greven puts it, supposed political problem-solving and scientific research epistemically integrate into a political-scientific power complex [58]. The illusion of knowledge about the future clearly verges on ideology.

Confronted with the fact that (multiple) prognoses only create an illusion of knowledge instead of scientific knowledge, scientists might answer that they are using the best instruments available. One is reminded of the person holding a hammer and seeing every problem as a nail (according to Paul Watzlawick).

It is by nature impossible to rationally dissolve this dilemma because knowing the future remains a paradox. However, there are ways to reduce illusions and prevent one-sidedness and false conclusions.

\section{Ways to think about the future in a scientific way}

\section{From knowledge creation to scientific anticipation}

The human brain is trained to anticipate future developments. The capability of mental time travel into the future, or the construction of alternative, possible situations "may hold the key to the evolution of such characteristically human phenomena as agriculture, morality, philosophy, science, technology, and trade" [59]. Our cognitive capacity to anticipate complex, alternative environments to think and plan ahead makes us human [60]. Anticipation of the future is indeed based on knowledge about the past but anticipating is not the same as knowing the future - in everyday life as well as in science. Of course the social sciences want to supply a crystal ball [61] but this desire will be unfulfilled. Moreover, a crystal ball is not needed (or even counterproductive) to expose the future.

For anticipation, the linear path from not knowing to scientifically knowing something $[62,63]$ is of minor importance. To think about the future in a scientific way we have to accept that we cannot know the future. Not knowing the future means to know that some parts of the puzzle are and will always be missing [9]. That does not mean that we do not know anything about the future.

We can, for instance, explain how the transformation of political systems worked in the past. More precisely, we can use prognoses to predict how it most likely happened in the past. We can also explain that ceteris paribus assumptions are not valid for long-term future developments. Hence, we do not know how a political transformation will take place in the future. However, we know something about what could happen under certain conditions without being able to clarify what 'could' in this context means. Following that, accepting that the future is essentially not knowable still allows anticipation of and strategic thinking about alternative futures [54, 55, 64].

For a SEF, it might be useful to think in terms of anticipation rather than in terms of knowledge and knowledge creation.

From determinism to complexity

If knowledge is not a central concept in a SEF, it is just logical to assume that we live in a world that cannot be known or scientifically explained. A deterministic worldview with clear causal relationships and determined structures is already considered an antiquated worldview. Unfortunately, the ceteris paribus caveat is far too often overlooked or ignored. Then, the analytical category of a deterministic worldview transforms into an unintentionally accepted truth and one may belief that the future is actually foreseeable and controllable.

First, thinking about the future in a scientific way means to be transparent and clear on the worldview taken as a basis. Second, it is very useful for a SEF to be clear in one's mind that our world is not deterministic, not eschatological, not easy to understand, and of course not to predict because for example of contingency in human behaviour $[65,66]$ and emergence in social systems [67]. In short, a worldview with a clear reference to complex structures and complex dynamics is more adequate for a SEF than a simplistic worldview because there are always more things and possibilities of change that we can grasp, oversee, understand or know.

\section{From critical rationalism to discursive scepticism}

According to Kurt Hübner, history is characterized by ambiguity, uncertainty, absurdity, nonsense and error [32]. Weber must have had a similar concept in mind when he stated that the social sciences can never explain things universally but only partly and always temporarily. Francis Bacon had already pointed out that 'truth is the daughter of time' [68]. Popper's notion of critical rationalism was the first attempt to create scientific knowledge against this background. In his view, scientific knowledge (about what already happened) is rationally justified, incomplete, temporary, falsifiable, critically reflected, created in discourse and related to the factual and in principle observable. No wonder critical rationalism turned out to be an important and useful guiding principle for science.

It is helpful to think about the future as an open and inherently contingent room in time without facticity, fluid structures and dynamics. Future does not have a logical frame 
of references, and future events cannot be falsified before they happen. Thinking about the future eludes probability and must be based on the concept of multiple, alternative but hypothetical futures, which can only be mentally constructed [68-70]. Thus, probable explanations and prognoses about the future are impossible and critical rationalism cannot be a valid guiding principle for exposing the future in a scientific way.

Still, rational justification is important for a SEF to explain what happened so far (past) because herein lie all foundations for future developments. However, rational justification should not be overrated. First, because there are always multiple and sometimes incommensurable perspectives on what happened in the past. Second, because there is no way to calculate complex long-term dynamics.

A SEF should allow for scientific statements about possible, alternative developments. Explanations cannot be used to justify these statements because they are prognoses about the past. Another form of explanations is needed instead. The justification of alternative mental constructions needs prognoses with the aim to illustrate rather than to explain future developments. Prognoses just illustrating rather than explaining future developments (leaving out the question what that is for now) can create a justification for mental constructions but only under the condition of acceptance by others. Following that, and having in mind that prognoses about the future are much more uncertain than about the past, the role of critical discourse in a SEF is fundamental.

The concept of a SEF as described here is actually not so different from the definition of normal science. This definition just highlights why thinking about the future needs more discursive scepticism. However, the introduction of so-called 'illustrative prognoses' [9] has major consequences on the rules of "the game called in empirical science" as Popper described it [14].

From explanatory prognosis to illustrative thought experiments

Poser describes five different forms of so-called methodological regulations that are based on a broad yet eclectic integration of works from Stephen Toulmin, Stephan Körner, Kurt Hübner and Yehuda Elkana [12]. Because methodological regulations are numerous, I just want to highlight some basic rules. Although only described superficially, these regulations can help to compare and evaluate diverse forms of future studies as scenarios, prognoses or risk analysis roughly from different points of view. Hence, they can make the products of future studies accessible for a more comprehensive and deeper analysis.

Cognitive interest First, the aims of doing research (the cognitive interest) in a SEF cannot include concrete recommendations for how to act in the face of an uncertain future, as thinking about the future cannot reduce uncertainty or insecurity. Recommendations can of course include descriptions of possible ways to proceed, depicting a room to manoeuvre instead of giving concrete advice for how to act successfully because there is nothing like a best strategic choice in terms of objectivity. In addition, an important cognitive interest in a SEF might be the critical reflection of our cognitive patterns and biases influencing our thinking about future long-term developments (as well as about the past).

Research perspective Second, as future developments do not care about selective perspectives of disciplines and theories, the object of investigation can be defined very narrowly but thinking about its uncertain future developments needs to involve a comprehensive, interdisciplinary and broad perspective. Thinking about the future of China's political system, for instance, it might be useful to include economic, social, and even technological and ecological perspectives and influences.

Analytical concepts Third, a broad perspective calls for an open definition of elementary, analytical concepts and their relation to each other. The most important elementary concepts in social science refer to the human being and its social behaviour. For a SEF, it is not of primary importance which concept of an analytical idea of the man is used (e.g. the homo oeconomicus or the homo sociologicus) but how many alternative concepts are equally considered. Another set of important concepts refers, for instance, to collective behaviour or the transformation of social systems. To think about alternative future developments, multiple perspectives in the sense of competing instruments to understand and explain social transformation could be helpful. That self-critical notion is already integrated in the concept of a scientific thinking about the future, and it is even more important to reflect it on a methodological layer in a SEF.

Accepted questions and answers Fourth, there are some rules concerning acceptable questions and answers in a SEF. Thinking about future means to address "what if?" questions. To answer this kind of questions with plausible illustrations of alternative developments, further questions have to be accepted as well, first and foremost questions about what science can know about the past and what not. The stand-alone "what will be?" question is not acceptable for a SEF.

Hard core Fifth, there are some rules regarding what Lakatos called the 'hard core' of a discipline, the rationalmethodological equivalent of the metaphysical worldview $[12,40]$. Here it is useful to understand the 'hard core' as a concept of science's formal codification instead of a set of non-falsifiable axioms with empirical relevance, as Lakatos defines it. I understand the hard core as a guiding principle for 
research activities related to a SEF and for the structure of reasoning in its products. I distinguish between a paradigmatic, a paradigm-critical, a dogmatic and a sceptical hard core. A 'sceptical attitude' against knowledge is coherent with the definition of a SEF given above, while a 'dogmatic attitude' is obviously less useful, and a paradigm-critical hard core is supposed to be more coherent than a paradigmatic core.

Sources of knowledge Sixth, the hierarchy of our sources of knowledge differ from the hierarchy we use to create knowledge about the past because the future has no facticity. "Sources of knowledge can be sense-experience, ratiocination, revelation, authority, tradition, analogy, competence, originality, novelty, beauty, and many others" [71]. Some of these forms are presumed to be obsolete even though they still have an impact. For my aim it is sufficient to stress that sources can come from a spectrum between experience (like observations and experiments) and pure reasoning (like thought experiments). As observations and experiments bow out as sources of knowledge about the future, a clear preference for thought experiments illustrating future developments seems to be adequate. Max Weber defines a thought experiment as an instrument we can use to construct relations between cause and effect under the assumption of an objective possibility. Our reality-oriented fantasy, to follow Weber, determines what can be defined as possible or impossible [43]. That said, experience-based sources of knowledge are needed to create plausibility of thought experiments and therefore for a SEF the entire spectrum of knowledge sources is needed to create plausible explanations illustrating possible futures. In that sense, on the one hand a SEF does not exclude creativity, art or fantasy at all but on the other hand it is essential that thought experiments must rely on an objective criterion for justification.

From probability to plausibility

Probability and possibility are critical to understand what can be accepted as an analytical proof, a justification, a probation, a critique, or a falsification [12]. Poser calls the rules defining what separates scientific statements from normal statements 'judicial regulations'. He highlights, for example, that Karl Popper's 'Logic of Scientific Discovery' and Lakatos' 'Proofs and Refutations' are perhaps two of the most influential studies on 'judical regulations'. That said, it is clear that I can only touch upon this complex field. As justification is a central concept in science and critique the origin of scientific development [72], I focus on them here to lay the groundwork for further discussion.

How can plausible explanations to illustrate possible futures be justified? First, they need to meet the condition of logical reasoning. Deduction is not an option, as it would create an illusion of knowledge by a linear extrapolation of the past. On the contrary, inductive reasoning is very useful to create hypotheses about possible future developments. The induction problem as described by Popper does not apply for a SEF because the future is defined as an open space of possibility that can only be illustrated but never known. Second, one may argue that inductive reasoning should not be accepted in plausible explanations because it cannot meet the condition of empirical significance. That is absolutely true, as future has no facticity. However, the condition of empirical significance was originally created to exclude metaphysical arguments in social science. Their subordinate objective is to make sure that explanations make sense [12] and in thinking about the future the formulation of hypotheses obviously makes more sense than creating an illusion of knowledge. Noteworthy is that hypotheses about the future are always based on our experience but they are not limited to it. Creating plausible explanations means recombining our experiences in new ways. Third, there is a condition of truth indicating that all parts of the explanans (theories, scientific laws and basic conditions used to explain something) have to be true. This condition can only be met in a critical discourse because plausible explanations can only be accepted as true temporarily. In sum, all necessary conditions for justifying a plausible explanation about the future can be met, and therefore the plausible illustration of alternative futures with thought experiments using scientific reasoning is possible.

There are three ways of how they can be criticised. First, by discovering underlying conditions that are not explicitly integrated in a plausible explanation. These implied basic conditions are usually ceteris paribus assumptions and should be questioned, also because hidden assumptions can easily transform into unperceived one-sidedness. Second, of course, by finding implausible explanations. As empirical evidence of future developments is lacking, the role of critical discourse becomes fundamental in the SEF. It should also be clear that the rhetorical munitions in this discourse are eventually based on how we understand the past. Third, plausibility can be criticised by finding hypotheses about future developments that cover a broader space of possibility by using more diverse concepts and theories.

\section{Conclusion: limitations and potentials}

In that article I have argued that there are severe problems in scientific thinking about the future that can lead to a widely shared illusion of knowledge within the scientific community and beyond. I pointed out that taking it seriously could ease the knowledge paradox regarding an uncertain and insecure future.

There are two major implications that can be derived from that. First, probable prognoses about the future are ideological claims rather than scientific statements. Second, rational 
justification of scenarios is possible although there are no falsifiable statements about the future. On the contrary, an inductive generation of alternative plausible and illustrative (not explanatory in a scientific sense) hypotheses is scientifically acceptable, as long as they do not aim to predict. The first and foremost objective of scenarios is to illustrate the future as an open space of possible developments that we cannot foresee; they are instruments to think about alternative futures.

Thinking about the future in a scientific way means accepting that we cannot know the future and that the world is characterized by structural and dynamic complexity. It means letting the ideal of rational explanations go and giving more room to discursive scepticism. For a SEF, explanatory prognoses have to be regarded with suspicion, and illustrative thought experiments have to be created in a scientific way using plausible explanations.

The limitations of my arguments pointed out above are obvious: First, probable prognoses can of course be useful instruments to think about the future [3]. Although probability has nothing to do with the future it can be used as a criteria for reliability of explanations about the future under the assumption of constant structures. The question then is whether this assumption is appropriate. For the near future, path dependencies are strong and structural changes do not have the time to unfold. In that case, probable explanations about the past can be applied to find answers about the future. For the mid- or long-term future, the assumption of constant structures becomes a pitfall that can create illusions.

Second, there is no set of rules that defines how to think about the future in a scientific way that just needs to be found. All arguments above can only be seen as a basis for further discussion and all concepts and rules for a SEF should be under constant critical reflection.

The future is the room to manoeuvre and not only the room to think about. Therefore, we have to be pragmatic in handling uncertainty and insecurity. Science can help to develop instruments to think about the future but it is not able to answer the question of when to apply what instruments. The biggest potential from this set of rules, although not exhaustive and illustrated, lays in its capability to distinguish between good and bad scenarios, between real alternative thought experiments and multiple prognoses. This potential becomes more and more important as scenarios increasingly enjoy great popularity while a comprehensive philosophy of future studies is still missing.

Acknowledgments I thank Dr. Rachel Folz, Prof. Dr. Hanns W. Maull, Oliver Read and the two reviewers for their valuable comments and critique.

Open Access This article is distributed under the terms of the Creative Commons Attribution License which permits any use, distribution, and reproduction in any medium, provided the original author(s) and the source are credited.

\section{References}

1. Böschen S, Weis K (2007) Die Gegenwart der Zukunft. Perspektiven zeitkritischer Wissenspolitik. VS Verlag für Sozialwissenschaften, Wiesbaden

2. Koselleck R (2000) Zeitschichten. Studien zur Historik. Suhrkamp, Frankfurt am Main

3. Gabriel J (2013) Der wissenschaftliche Umgang mit Zukunft. Eine Ideologiekritik am Beispiel von Zukunftsstudien über China. Springer VS, Wiesbaden

4. Walsby H (1947) The domain of ideologies. A study of origin, structure and development of ideologies. William MacLellan, Glasgow

5. Gerring J (1997) Ideology: a definitional analysis. Political Res Q 50: 957-994

6. Neuhaus C (2006) Zukunft im Management. Orientierungen für das Management von Ungewissheit in strategischen Prozessen. Systemische Forschung im Carl-Auer-Verlag, Heidelberg

7. Luhmann N (2002) Zeit. In: Luhmann N (ed) Einführung in die Systemtheorie. Carl-Auer-Systeme Verlag, Heidelberg, pp 195-220

8. Heidegger M (1967) Sein und Zeit. Max Niemeyer, Tübingen

9. Zimmerli WC (1998) Zeit als Zukunft. In: Weis K (ed) Was treibt die Zeit? Entwicklung und Herrschaft der Zeit in Wissenschaft, Technik und Religion. Deutscher Taschenbuch Verlag, München, pp 263290

10. Shackle GLS (1979) Imagination and the nature of choice. Edinburgh University Press, Edinburgh

11. Wohlgenannt R (1969) Was ist Wissenschaft? F. Vieweg, Braunschweig

12. Poser H (2001) Wissenschaftstheorie. Eine philosophische Einführung. Reclam, Stuttgart

13. Weingartner P (1971) Einführung in die Hauptprobleme. FrommannHolzboog, Stuttgart-Bad Cannstatt

14. Popper KR (1966) Logik der Forschung. Mohr, Tübingen

15. Baumann P (2002) Erkenntnistheorie. Metzler, Stuttgart

16. Williamson J (1999) Countable additivity and subjective probability. Br J Philos Sci 50:401-416

17. Barnes EC (1998) Probabilities and epistemic pluralism. Br J Philos Sci 49:31-47

18. Zoglauer T (1997) Einführung in die formale Logik für Philosophen. Vandenhoeck \& Rup, Göttingen

19. Habermas J (1984) Vorstudien und Ergänzungen zur Theorie des kommunikativen Handelns. Suhrkamp, Frankfurt am Main

20. Popper KR (1966) A comment on miller's new paradox of information. Br J Philos Sci 17:61-69

21. Werndl C (2009) What are the new implications of chaos for unpredictablity. Br J Philos Sci 60:195-220

22. Kosow H, Gassner R (2008) Methoden der Zukunfts- und Szenarienanalyse. Überblick, Bewertung und Auswahlkriterien. Institut für Zukunftsstudien und Technologiebewertung, Berlin

23. Mietzner D, Reger G (2005) Advantages and disadvantages of scenario approaches for strategic foresight. Int J Technol Intell Plan 1: 220-239

24. Bishop P et al (2007) The current state of scenario development: an overview of techniques. Foresight 9:5-25

25. Blass E (2003) Researching the future: method or madness? Futures 35:1041-1054

26. Cornish E, World Future Society (1977) The study of the future. An introduction to the art and science of understanding and shaping tomorrow's world. The Society, Washington

27. Kreibich R (2008) Zukunftsforschung für die gesellschaftliche Praxis. ArbeitsBericht 26

28. Schwartz $\mathrm{P}$ (1995) The art of the long view. Planning for the future in an uncertain world. Currency Doubleday, New York

29. Van Notten PWF, Rotmans J, van Asselt MBA, Rothman DS (2003) An updated scenario typology. Futures 35:423-443 
30. Bradfield R, Wright G, Burt G, Cairns G, Van der Heijden K (2005) The origins and evolution of scenario techniques in long range business planning. Futures 37:795-812

31. Marien M (2002) Futures studies in the 21 st Century. A reality-based view. Futures 34:261-281

32. Hübner K (1979) Kritik der wissenschaftlichen Vernunft. Alber, Freiburg [Breisgau], München

33. Hübner K (1971) Philosophische Fragen der Zukunftsforschung. Studium Generale Zeitschrift für die Einheit der Wissenschaften im Zusammenhang ihrer Begriffsbildungen und Forschungsmethoden. Studium Generale 24:851-864

34. Grunwald A (2009) Wovon ist die Zukunftsforschung eine Wissenschaft. Zukunftsforschung und Zukunftsgestaltung. Beiträge aus Wissenschaft und Praxis. Springer Verlag, Berlin, pp 25-35

35. Hines A (2003) Futures of futures: a scenario salon. Foresight 5:2835

36. Krawczyk E, Slaughter R (2010) New generations of futures methods. Futures 42:75-82

37. Andersson G (1973) Methods in futures studies. A view from the theory of science. Technol Forecast Soc Chang 5:305-319

38. Brockhaus (2010) Wissenschaft. Brockhaus - Die Enzyklopädie

39. Kuhn TS (1962) The structure of scientific revolutions. University of Chicago Press, Chicago

40. Lakatos I (1970) Falsification and the methodology of scientific research programmes. In: Lakatos I, Musgrave A (eds) Criticism and the growth of knowledge. Proceedings of the international colloquium in the philosophy of science, London, 1965, volume 4. Cambridge University Press, Cambridge, pp 91195

41. Nowotny H (1999) Es ist so. Es könnte auch anders sein. Über das veränderte Verhältnis von Wissenschaft und Gesellschaft. Suhrkamp, Frankfurt am Main

42. Lobkowicz N (1976) Erkenntnisleitende Interessen. In: Hübner K, Lobkowicz N, Lübbe H, Radnitzky G (eds) Die Politische Herausforderung der Wissenschaft. Gegen eine ideologisch verplante Wissenschaft. Hoffmann und Campe, Hamburg, pp 55-60

43. Weber M (1985) Die "Objektivität" sozialwissenschaftlicher und sozialpolitischer Erkentnnis. Gesammelte Aufsätze zur Wissenschaftslehre. http://www.zeno.org/nid/20011440104, Accessed 23 July 2013

44. Kuhn TS (1970) Logic of discovery or psychology of research? In: Lakatos I, Musgrave A (eds) Criticism and the growth of knowledge. Proceedings of the international colloquium in the philosophy of science, London, 1965, volume 4. Cambridge University Press, Cambridge, pp 1-23

45. Ritsert J (1996) Einführung in die Logik der Sozialwissenschaften. Westfälisches Dampfboot, Münster

46. Habermas J (2004) Analytische Wissenschaftstheorie und Dialektik. Vordenker Summer Edition:1-20

47. Schneider V (2008) Komplexität, politische Steuerung, und evidenz-basiertes Policy-Making. In: Janning F, Toens K (eds) Die Zukunft der Policy-Forschung. Theorien, Methoden, Anwendungen. VS Verlag für Sozialwissenschaften, Wiesbaden, pp $55-70$

48. Glenn JC, Gordon TJ, Millennium Project (2009) Futures research methodology. Millennium Project, Washington

49. Lentsch J, Weingart P (2011) Quality control in the advisory process: towards an institutional design for robust science advice. In: Lentsch J, Weingart P (eds) The politics of scientific advice. Cambridge University Press, Cambridge, pp 353-374

50. Weingart P, Lentsch J (2008) Wissen, Beraten, Entscheiden. Form und Funktion wissenschaftlicher Politikberatung in Deutschland. Velbrück, Weilerswist

51. Luhmann N (2006) Beobachtungen der Moderne. VS Verlag für Sozialwissenschaften, Wiesbaden
52. Schaper-Rinkel P (2006) Der Zeit-Raum der Zukunft als politischer Handlungsraum. In: Krause B, Fricke D, Pippart N, Meyer T (eds) Chronotopographien - Agency in ZeitRäumen. Lang, Frankfurt am Main, pp 185-196

53. Luhmann N (2000) Die Politik der Gesellschaft. Suhrkamp, Frankfurt am Main

54. Habegger B (2010) Strategic foresight in public policy: reviewing the experiences of the UK, Singapore, and the Netherlands. Futures 42:49 58

55. van der Heijden K (2002) The sixth sense: accelerating organizational learning with scenarios. Wiley, Chichester

56. Godet M, Roubelat F (1996) Creating the future: the use and misuse of scenarios. Long Range Plan 29:164-171

57. Beck U (1999) World risk society. Blackwell Publishers, Cambridge

58. Greven MT (2008) "Politik" als Problemlösung - und als vernachlässigte Problemursache. Anmerkungen zur PolicyForschung. In: Janning F, Toens K (eds) Die Zukunft der PolicyForschung. Theorien, Methoden, Anwendungen. VS Verlag für Sozialwissenschaften, Wiesbaden, pp 23-33

59. Suddendorf T, Corballis MC (1997) Mental time travel and the evolution of the human mind. Genet Soc Gen Psychol 123:133-167

60. Suddendorf T, Corballis MC (2007) The evolution of foresight: What is mental time travel, and is it unique to humans? Behav Brain Sci 30: 299-313

61. Haftendorn H (1996) Die Sehnsucht nach der Kritallkugel. Über Leistungsfähigkeit und Vorhersagen der Theorie der internationalen Politik. Int Politik 8:3-7

62. Böschen S et al (2004) Handeln trotz Nichtwissen. Vom Umgang mit Chaos und Risiko in Politik, Industrie und Wissenschaft. Campus, Frankfurt am Main

63. Beck U (2007) Weltrisikogesellschaft. Auf der Suche nach der verlorenen Sicherheit. Suhrkamp, Frankfurt am Main

64. Lucas JR (1989) The future. Basil Blackwell, Cambridge

65. Makropoulus M (2004) Kontingenz. Arch Eur Sociol 45:369-399

66. Holzinger M (2007) Kontingenz in der Gegenwartsgesellschaft. Dimensionen eines Leitbegriffs moderner Sozialtheorie. Transcript, Bielefeld

67. Luhmann N (1999) Die Gesellschaft der Gesellschaft. Suhrkamp, Frankfurt am Main

68. Nassehi A (1993) Die Zeit der Gesellschaft: auf dem Weg zu einer soziologischen Theorie der Zeit. Westdeutscher Verlag, Opladen

69. Minx E, Böhlke E (2006) Denken in alternativen Zukünften. Int Politik 12:14-22

70. Pedersen SA, Witt-Hansen J (1982) Futures Research. A Philosophical Analysis of Its Subject-Matter and Methods. Roskilde Universitetscenter

71. Elkana Y (1981) A programmatic attempt at an anthropology of knowledge. In: Everett M (ed) Sciences and cultures. D. Reidel Publishing, Dordrecht, pp 1-76

72. Lakatos I (1979) Beweise und Widerlegungen. Die Logik mathematischer Entdeckungen. Vieweg, Braunschweig

73. Malaskas P (2000) Knowledge and information in futurology. Foresight 2:237-244

Dr. Johannes Gabriel is founder and director of the Institute for Applied Foresight Intelligence (IAFI), a research and consulting firm based in Berlin, Germany. His areas of expertise include China, Indonesia, international relations and informal networks in transition societies. He was a $\mathrm{PhD}$ fellow with the Society and Technology Research Group (Daimler AG) and earned his $\mathrm{PhD}$ at the University of Trier. He is also a non-resident fellow with the Global Public Policy Institute (GPPi) 